Z. JIANG, ${ }^{1}$ Y. ZHU, ${ }^{2}$ L. XU, ${ }^{2}$ J. G. XU, ${ }^{2}$ and Y. D. $\mathrm{GU}^{2}$

\title{
FUNCTIONAL CHANGES IN MOTOR ENDPLATES OF THE TARGET MUSCLE AFTER AMPUTATION OF THE C7 NERVE ROOT
}

\author{
Received February 5, 2013.
}

There are limited data on structural and functional changes in motor endplates and muscle fibers in the target muscle following amputation of the 7 th cervical nerve root, a transplantation-related procedure in surgical treatment in the case of avulsions of the brachial plexus roots. We examined functional changes in these structures using stimulated singlefiber electromyography (sSF-EMG) in an animal model. Unilateral amputation of the 7 th cervical nerve root was performed in 36 male rats, and the $m$. triceps brachii muscle was tested by SSF-EMG at different time points. We observed significant differences in the jitter (mean consecutive difference, MCD, of the latencies between adjacent muscle fibers) at postamputation weeks 1, 2, 4, and 6. The post-operation fiber density (FD) values within the zone of effective stimulation also gradually increased. At post-amputation weeks 8 and 12 , the jitter values returned to normal levels, whereas FD values continued to rise. Our results indicate that the post-amputation compensatory processes in the target muscles of the 7 th cervical nerve root are completed at 9-12 weeks after amputation.

Keywords: 7 th cervical nerve root, nerve-muscle transmission, stimulated single-fiber electromyography (sSF-EMG), jitter, fiber density.

\section{INTRODUCTION}

Since Y. D. Gu first proposed a transposition operation of the healthy 7 th cervical nerve root in 1986, this procedure has been generally recognized as the main surgical treatment for traumatic avulsions of the brachial plexus roots [1-3]. Long-term clinical practice has proven that amputation of the 7 th cervical nerve root does not cause apparent or permanent functional damage [4-7]. This theory has been verified in microdissection and animal experiments [8,9]. However, the time course and electrophysiological compensatory mechanisms remain unclear.

There has been extensive research on the pattern of morphological changes in completely denervated skeletal muscle motor endplates [10,11]. Partial denervation of the hindlimb muscles has been achieved by sectioning spinal roots or injecting a blocking agent

\footnotetext{
${ }^{1}$ Yijishan Hospital, Wannan Medical College, Wuhu, China.

${ }^{2}$ Huashan Hospital, Shanghai Medical College, Fudan University, Shanghai, China.

Correspondence should be addressed to:

Z. Jiang (e-mail jiangzongyuan@medmail.com.cn),

L.Xu (e-mail Dr_Xulei86@fudan.edu.cn),

Y.Zhu (e-mail dr_zhuyi@163.com),

J. Xu (e-mail xujianguang@hotmail.com),or

Y. D. Gu (e-mail dr_guyudong@163.com)
}

to induce muscular paralysis [12-20]. However, there has been little respective research on the microscopic level.

The single-fiber electromyography (SF EMG) technique proposed in the 1960s provided recording of the data from two neighboring muscle fibers of the same motor unit. In this case the latency between the stimulus and response varies at consecutive stimulations. This phenomenon is called neuromuscular jitter and is explained by variation in the time taken by endplate potentials at the neuromuscular junction to reach the suprathreshold level of depolarization [2123]. Neuromuscular junction jitter is determined by relations between the amount of acetylcholine (ACh) quantal release and sensitivity of the postsynaptic membrane and reflects the functional state of the motor endplate [24-25]. Compared to traditional autonomic contractile SF-EMG (vSF-EMG), stimulated SF-EMG (sSF-EMG) is better suited for children [26, 27] and in animal studies [28]. The application of sSF-EMG seems promising as a sensitive detection method for minimal changes in denervated muscles.

To gain an insight into the compensatory mechanisms after partial denervation of a principal muscle ( $m$. triceps brachii) following amputation of the 7 th cervical nerve root, we utilized SF-EMG to 
detect changes in the jitter and muscle fiber density (FD) at different time periods after surgery in experiments on rats.

\section{METHODS}

Animal Model. Thirty-six male SD (Sprague-Dawley) rats $(250-350 \mathrm{~g})$ were randomly divided into six groups. After anesthesia with $10 \%$ chloral hydrate $(0.3$ $\mathrm{ml} / \mathrm{kg}$ ), the animal was secured in the supine position. An incision was made beneath the right clavicle, the major and minor pectoral muscles were retracted, and a retractor was used to expose the roots of the brachial nerve plexus. The 7 th cervical nerve root was severed, with the distal end flipped towards the proximal end and secured to the sarcolemma of the minor pectoral muscle with a 10/0 atraumatic suture, in order to create a defect of at least $4 \mathrm{~cm}$. A 4/0 nylon silk suture was used to close the incision. Routine animal feeding procedures were carried out after the operation.

SF EMG Recording. Animals were anesthetized and secured, as described above. The entering incision was made just beneath the right clavicle, and the roots of the brachial nerve plexus were isolated to ensure that the 7 th cervical nerve root remained severed. The animal was removed from the group if regeneration of the nerve fibers had occurred. The triceps brachii and its ends were exposed, and the points at which the radial nerve enters the triceps brachii were isolated.

The electromyographic procedures (Alpine BioMed ApS, Electromyograph/Evoked potential equipment, Keypoint, Denmark, software serial number 2114) were preliminarily prepared by using Teflon to cover an exposed tip of the single electrode as the negative pole. The stimulating electrode was placed $1 \mathrm{~cm}$ from the origin of the triceps brachii, with its positive pole $0.5 \mathrm{~cm}$ from the distal end of the negative pole. Pulse stimulation was initiated at $10 \mathrm{sec}^{-1}, 50 \mathrm{msec}$ duration, and 1-4 $\mathrm{mA}$ current that was gradually increased by $0.1 \mathrm{~mA}$ increments until tiny contractions of the muscle appeared. The single-fiber recording electrode (Medtronic Co., Keypoint model) was inserted into the muscle $2 \mathrm{~cm}$ from the distal end of the negative electrode; the depth wath gradually adjusted by carefully rotation of the pinhead until a sufficiently high-amplitude stable action potential (AP) was obtained. A $500-\mathrm{Hz}$ low-frequency filter was used to obtain a stable baseline. The amplifier gain was set at $100 \mu \mathrm{V} /$ div to $1 \mathrm{mV} /$ div adjustable.
The jitter can be expressed as s.d. of the variations (between the stimulus and response or between two single fiber APs). Due to superimposed slow changes in the mean latency between APs that may occur during long-lasting activity, the variations are expressed as mean values of the consecutive differences (MCDs) of successive interpotential intervals calculated according to the following formula:

$$
\mathrm{MCD}=\frac{\left|I P I_{1}-I P I_{2}\right|+\left|I P I_{2}-I P I_{3}\right|+\ldots+\left|I P I_{n}-1-I P I_{n}\right|}{n-1}
$$

where IPI $_{i}$ is the interspike interval or, when nerve stimulation is used, the stimulus-response interval.

The average jitter value was calculated from jitter recordings from 20 separate points/sites (100 continuous impulses per point). The mean value of MCD and mean sorted-data difference (MSD) were calculated. If the $\mathrm{MCD} / \mathrm{MSD}$ ratio was greater than 1.25 , the MSD value was used instead of the MCD. Blocking and its percentage of occurrence were then determined by changes in the waveforms. Direct muscle stimulation data resulting in jitter values $<5 \mathrm{msec}$ were eliminated. The fiber density, FD, was calculated as the average number of simultaneously firing single muscle fibers within the recording radius of the electrode. It was defined as the mean number of associated single fiber potentials with amplitude $>200 \mathrm{mV}$ and rise time $<300 \mathrm{~mm}$ that fire almost synchronously with the initially identified potential. The FD values $>3$ were considered abnormal.

All statistical analyses were performed using SPSS 13.0 software (SPSS Inc., USA). The paired $t$-tests and Wilcoxon signed-rank test were used to compare jitter values between groups; differences with $P$ values less than 0.05 were considered statistically significant.

\section{RESULTS}

Data from 942 muscle fibers were successfully recorded from $36 \mathrm{SD}$ rats. The values of jitter ranged from 2 to $135 \mathrm{msec}$; those $\leq 5 \mathrm{msec}$ were discarded. We tested 418 triceps brachii fibers from normal sides, and the jitter range was determined to be $16.0 \pm 6.4 \mathrm{msec}$.

Bilateral sSF-EMG was performed on the triceps brachii muscle at different time points (Fig. 1). Based on the actual jitter value of each animal, we calculated the MCD and MIPI values and plotted MCD histograms (Fig. 2). Based on the statistical characteristics of jitter values obtained from the triceps brachii muscle, 


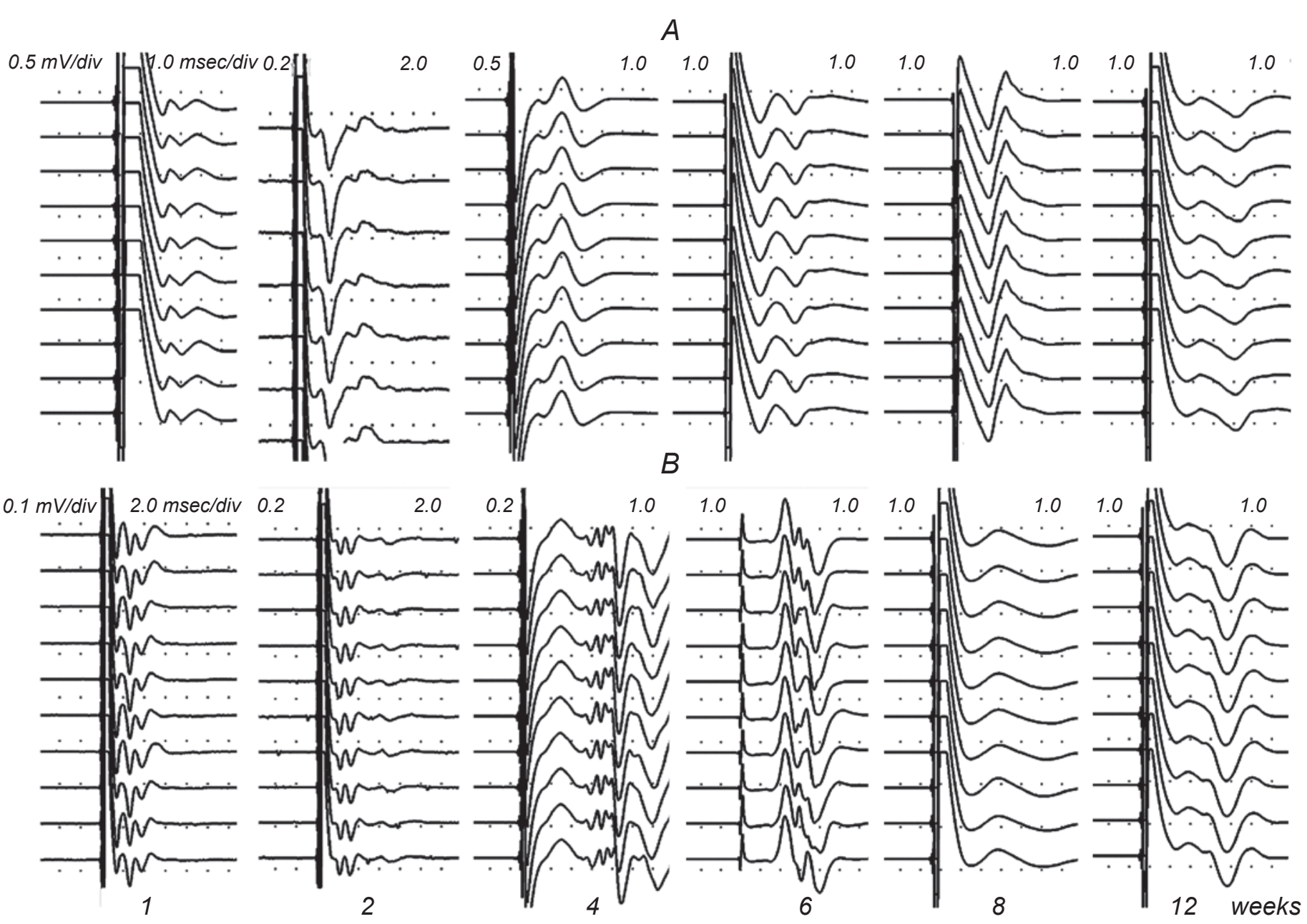

F i g. 1. SF-EMG waveform collection. A) SF action potential (AP) figures in the control (A) and experimental (B) groups at weeks 1 to 12 (indicated below). Calibrations of the amplitude $(\mathrm{mV} / \mathrm{div})$ and time $(\mathrm{msec} / \mathrm{div})$ are shown above the records at the left and right, respectively.

Р и с. 1. Записи, отримані за допомогою «одноволоконної» ЕМГ в різні терміни після перерізки корінця $C 7$.

the data were analyzed by the paired $t$-test and Wilcoxon signed-rank test. The results in Fig. 3 show that the MCD in the test group was greater than that in the control group at one week after amputation of the 7 th cervical nerve root $\left(P_{1}=0.0016\right)$. The MCD value increased gradually and remained greater than that in the control group within weeks 2 to 6 $\left(P_{2}=0.0001, P_{4}=0.0277\right.$, and $\left.P_{6}=0.0277\right)$. At weeks 8 to 12 , the MCD values returned to normal levels $\left(P_{8}=0.173\right.$ and $\left.P_{12}=0.2321\right)$. A minimal amount of blocking was observed in the experimental group within weeks 4 and 6 (Fig. 4).

The FD values began to increase at the first week, and the FD values continued to rise alongside the MCD during weeks 2-6. At weeks 8-12, the MCD returned to normal levels, while the FD values were still higher than those in the control group (Figs. 5 and 6).

\section{DISCUSSION}

Several methods allow researchers to detect functional changes in cases analogous to ours, such as, e.g., altered ACh quantal release [29-32]. However, an SFEMG technique can provide information from greater numbers of motor units than using surface or concentric electrodes; this technique is easier to operate and less invasive. The jitter value sensitively characterizes the functions of neuromuscular junctions, and the respective observations are reliable and important in clinical applications for functional assessment [33].

The MCD began to increase one week after 

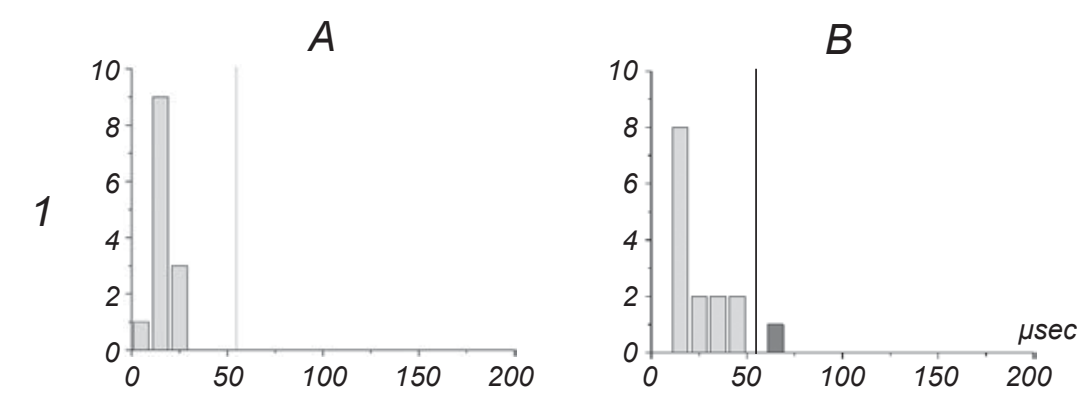

F i g. 2. Representative MCD distributions based on the detected sSF-EMGs in the control (A) and experimental (B) groups at the 1 st to the 12th week (indicated at the left). Filled columns show jitters $>55 \mu$ sec; the upper limit of the normal value is shown by vertical lines.

Р и с. 2. Розподіли значень MCD згідно 3 результатами «одноволоконної» ЕМГ у контролі $(A)$ та в експериментальній групі $(B)$ на 1-ий - 12-ий тижні (вказано
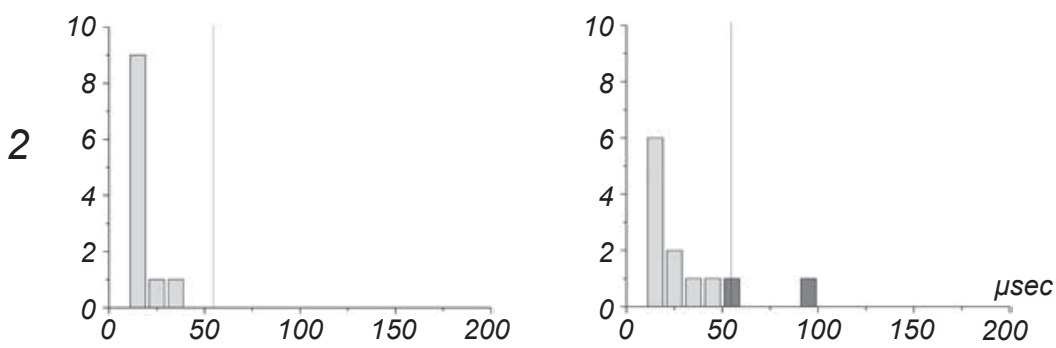
зліва).
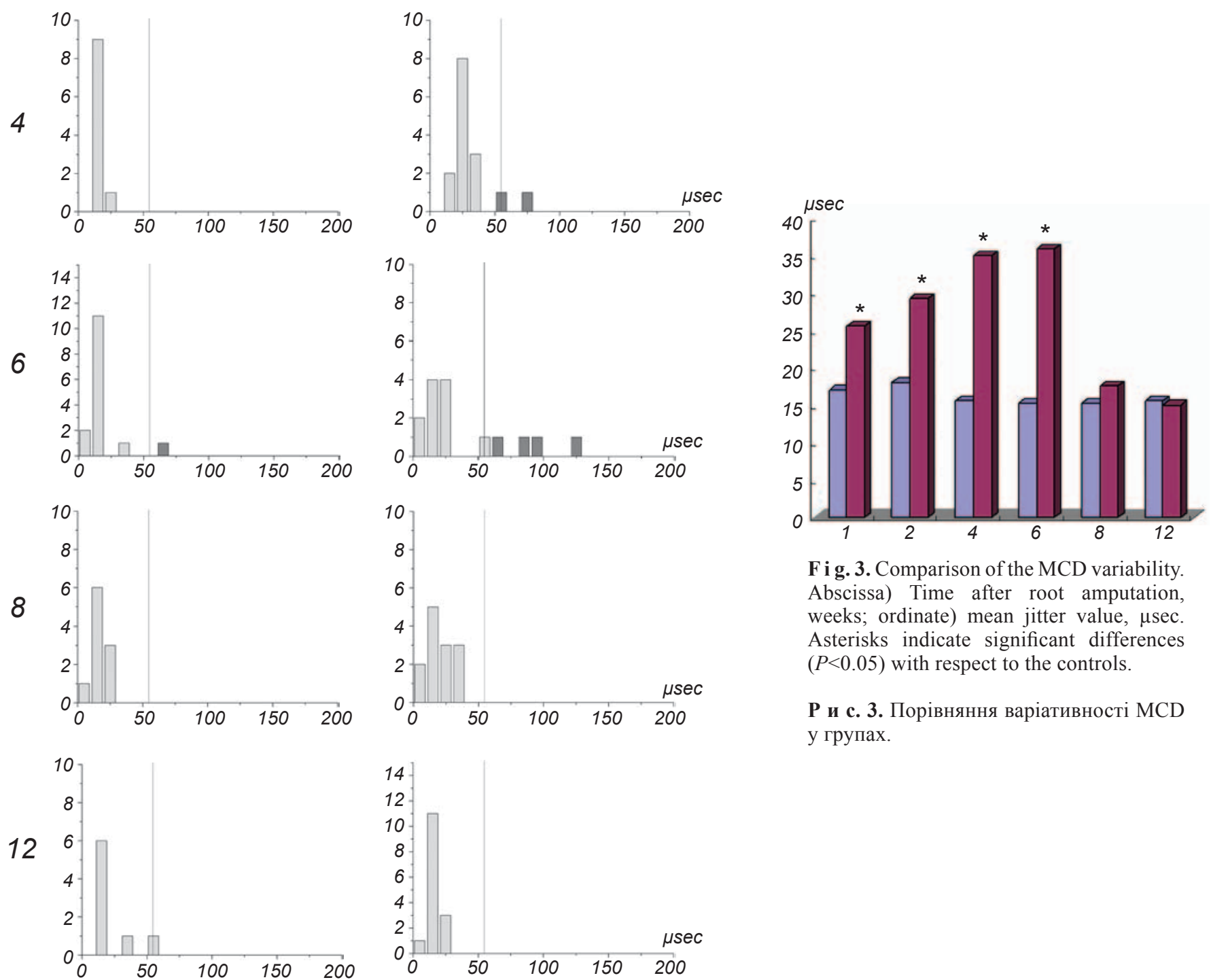

F i g. 3. Comparison of the MCD variability. Abscissa) Time after root amputation, weeks; ordinate) mean jitter value, $\mu$ sec. Asterisks indicate significant differences $(P<0.05)$ with respect to the controls.

Р и с. 3. Порівняння варіативності MCD у групах. 

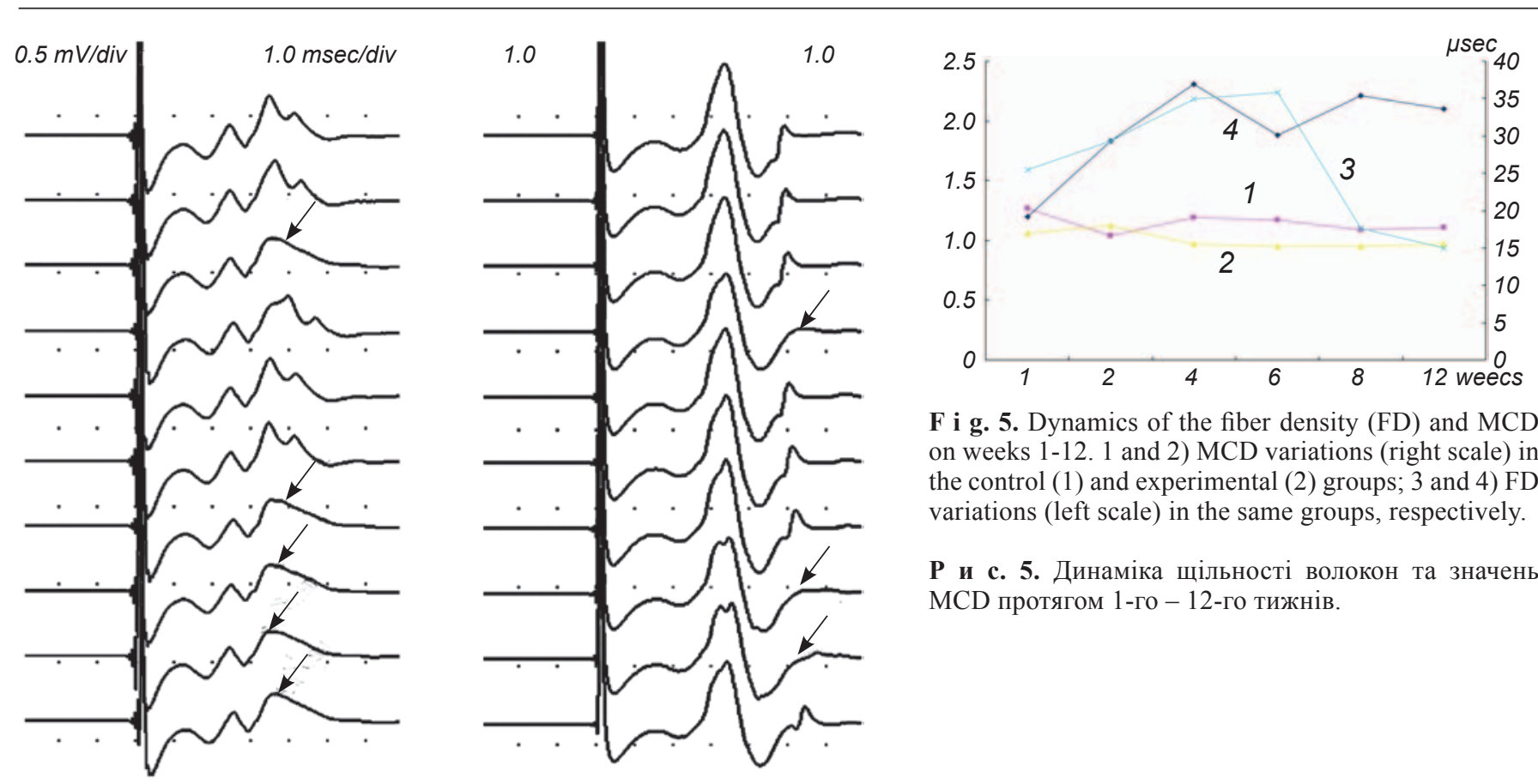

F i g. 5. Dynamics of the fiber density (FD) and MCD on weeks 1-12. 1 and 2) MCD variations (right scale) in the control (1) and experimental (2) groups; 3 and 4) FD variations (left scale) in the same groups, respectively.

P и с. 5. Динаміка щільності волокон та значень MCD протягом 1-го - 12-го тижнів.

F i g. 4. Blocking of single fiber action potentials (shown by arrows). It was $50 \%$ on the 4 th week (A) and $30 \%$ on the 6 th week (B). Other designations are similar to those in Fig. 1.

Р и с. 4. Блокування потенціалів дії окремих волокон (вказано стрілками).

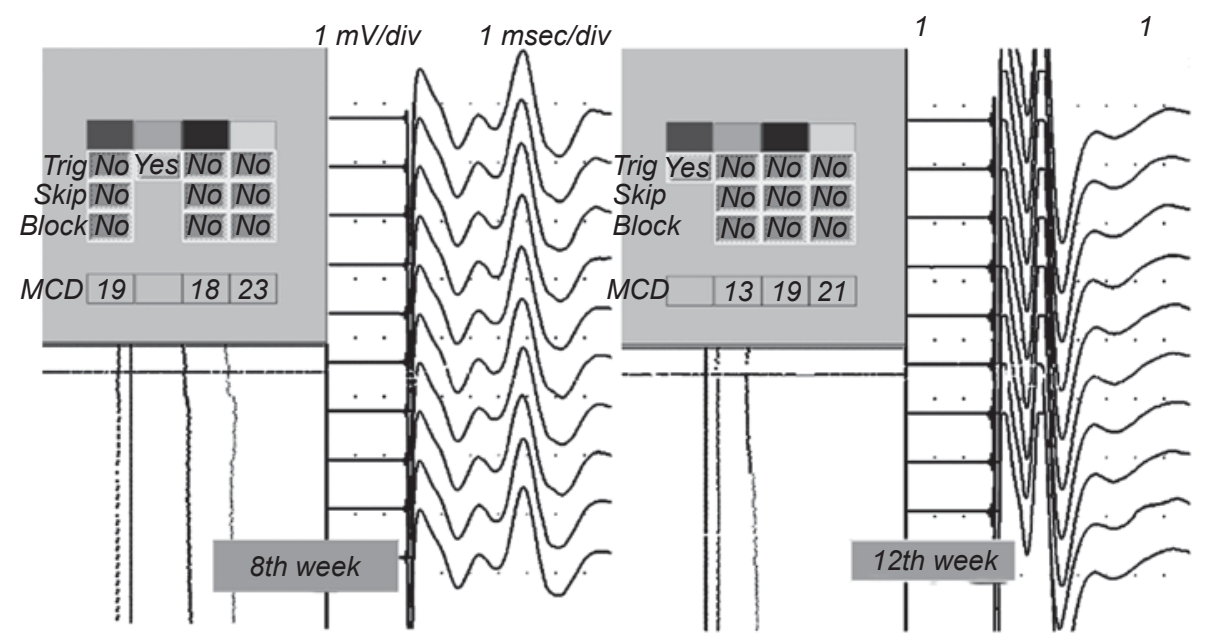

F i g. 6. Relationship between the jitter value and FD. A) Jitter value dropped to normal levels, but there was an unusual increase in the SF AP peak on the 8th week, indicating an increase in the FD. B) Similar changes were observed on the 12th week. Other designations are similar to those in Fig. 1.

Р и с. 6. Взаємовідносини між значеннями «дрижання» та щільності волокон.

root amputation. This value is smaller than that in the previous research; the latter showed that even completely denervated motor endplates showed changes four weeks later [16,34]. This is consistent with Tam's proposal [35] that compensatory changes take place even just three days after denervation.

The MCD value gradually increased two to six weeks after amputation, and it was distinctively greater in the experimental group. This illustrates the obvious weakening of the transmission function of the triceps brachii motor endplates. We also observed markedly increased jitter values at certain sites of the long head of the triceps brachii, whereas jitter results from the other sites were mostly nearly normal. This suggests that effects of denervation are not uniform; certain sites with decreased conduction might receive compensatory support from budding peripheral axons. At eight weeks, the MCD values decreased. No differences were found later on, suggesting that conducting functions returned to normal. 
Intramuscular neural stimulation allows one to provide more selective activation of motoneuronal axons, which reduces the number of recruited motor units $[36,37]$. Therefore, we used intramuscular neural stimulation at 5-7 $\mathrm{sec}^{-1}$.

Motor endplates are the main source of jitter. Within early stages of reinnervation, changes in the terminal end bulb of the axon cause noticeable variability in the ACh quantal release timing. Also, the time needed for transduction of excitation from the axon terminal to each fiber is different, ultimately causing the MCD to increase $[37,38]$. Blocking is a known pathological phenomenon that can increase jitter [33, 39]. It increases during the early stages of reinnervation before complete myelination of axonal terminals has been achieved. This produces conduction defects along the neural path and results in conduction blocking; the respective data might reveal valuable information regarding axonal regeneration [40]. We found a minimal amount of blocking within weeks 4 and 6 , suggesting that jitter is not affected by blocking, and that axonal regeneration begins around week 4 .

The FD increases when the process of compensatory proliferation begins [41]. The values of this index continued to increase during weeks 2 to 6 and remained at high levels at weeks 8-12. These results imply that compensatory triceps brachii proliferation began at week 1 or 2 but was not enough to compensate for decreased conducting function. After week 6, with axon regeneration and increased functional compensation, sustained fiber proliferation began to decrease or even stop. Nevertheless, the increase in the number of muscle fibers did not cease immediately. Therefore, the FD value was sustained; the duration of the respective changes is a topic for future experiments.

One of the major inadequacies of our study was the exclusion of other representative muscles innervated by the 7 th cervical nerve root. This might lead to deviations in the compensatory process. We also did not assess morphological changes. However, we found that, under conditions of the experiments used, compensatory recovery occurs in weeks 8 to 12 postamputation, and muscle fibers continue to proliferate. The compensatory process after amputation may be observed by using jitter and FD values obtained from sSF-EMG, which can be employed to explore compensatory mechanisms functioning after nerve amputation.

All experiments conformed to the National Institutes of
Health Guide for the Care and Use of Laboratory Animals (NIH Publication No. 80-23, revised 1996).

The authors, Z. Jiang, Y. Zhu, L. Xu, J. G. Xu, and Y. D. Gu, declare that they have no conflict of interest.

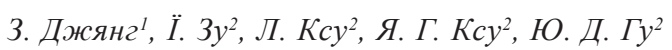

ФУНКЦІОНАЛЬНІ ЗМІНИ В МОТОРНИХ КІНЦЕВИХ ПЛАСТИНКАХ М' ЯЗА-ЦІЛІ ПІСЛЯ АМПУТАЦІЇ НЕРВОВОГО КОРІНЦЯ С7

\author{
1 Лікарня Їджішан Медичного коледжу Ваннан, Уху \\ (Китай). \\ 2 Лікарня Хуашан Шанхайського медичного коледжу при \\ Університеті Фудан, Шанхай (Китай). \\ P е 3 ю м е
}

Дані щодо структурних та функціональних змін у моторних кінцевих пластинках та м'язових волокнах м'яза-цілі після ампутації сьомого шийного нервового корінця (процедури в рамках трансплантаційного хірургічного лікування наслідків відриву корінців брахіального сплетіння) поки що обмежені. Ми досліджували функціональні зміни в згаданих структурах, використовуючи методику стимуляційної „одноволоконної” електроміографії в умовах експериментальної моделі на тваринах. Унілатеральну ампутацію сьомого цервікального нервового корінця було виконано на 36 щурах-самцях, і триголові м'язи плеча тестувалися за допомогою згаданої ЕМГ-методики в різні часові інтервали. Ми виявили істотні відмінності середніх варіацій (,дрижання", jitter, різниць між послідовними величинами) латентних періодів, характерних для прилеглих одне до одного м'язових волокон, у перший, другий, четвертий та шостий тижні після операційного періоду. В цей час щільність волокон у зоні ефективної стимуляції також поступово зростала. На восьмий-12-й тижні післяопераційного періоду значення варіацій (,дрижання”) поверталися до нормальних, тоді як значення щільності активованих волокон продовжували зростати. Наші результати свідчать про те, що післяампутаційні компенсаторні процеси в м'язах-цілях волокон нервового корінця С7 завершуються через дев'ять-12 тижнів після ампутації останнього.

\section{REFERENCES}

1. P. Songcharoen, S. Wongtrakul, and R. J. Spinner, "Brachial plexus injuries in the adult. Nerve transfers: the Siriraj Hospital experience," Hand Clin., 21, 83-89 (2005).

2. Y. D. Gu, "Contralateral seventh cervical nerve root transfer for 20 years," Chin. J. Hand Surg., 22, 193-194 (2006).

3. R. J. Spinner, A. Y. Shin, and A. T. Bishop, "Update on brachial plexus surgery in adults," Tech. Hand Upper Extrem. Surg., 9, 220-232 (2005).

4. Y. Gu, J. Xu, L. Chen, et al., "Long term outcome of contralateral C7 transfer: a report of 32 cases," Chin. Med. 
J. (Engl.), 115, 866-868 (2002).

5. Y. D. Gu, "How to judge the functional stature of $\mathrm{C} 7$ nerve root?" Chin. J. Hand Surg., 25, 129 (2009).

6. Y. D. Gu, G. M. Zhang, D. S. Chen, et al., "Seventh cervical nerve root transfer from the contralateral healthy side for treatment of brachial plexus root avulsion," J. Hand Surg. Br., 17, 518-521 (1992).

7. J. G. Xu, S. N. Hu, and H. Wang, "Study on clinical application of selective transfer of ipsilateral C7 nerve root," Chin. J. Traumatol. (Eng. Ed.), 3, 169-171 (2000).

8. L. Chen and Y. D. Gu, "An experimental study of the treatment of root avulsion of brachial plexus using contralateral $\mathrm{C} 7$ nerve neurotization (nerve transfer)," Zhonghua Wai Ke Za Zhi, 30, 525-527 (1992).

9. W. Lu, J. G. Xu, and Y. D. Gu, "The microanatomical study of the functional orientation of the $\mathrm{C} 7$ nerve roots in rats," Chin. J. Hand Surg., 19, 46-50 (2003).

10. J. G. Xu and Y. D. Gu, "An experimental study of degenerative morphology and enzyme histochemistry in denervative skeletal muscles," Zhongguo Xiu Fu Chong Jian Wai Ke Za Zhi, 13, 202 (1999).

11. J. G. Xu and G. Y. D., "Experimental study of rat skeletal muscle atrophy due to denervation," Chin. J. Exp. Surg., 21, 57-58 (2004).

12. M. C. Brown and R. Ironton, "Sprouting and regression of neuromuscular synapses in partially denervated mammalian muscles," J. Physiol., 278, 325-348 (1978).

13. A. de Paiva, F. A. Meunier, J. Molgo, et al., "Functional repair of motor endplates after botulinum neurotoxin type A poisoning: biphasic switch of synaptic activity between nerve sprouts and their parent terminals," Proc. Natl. Acad. Sci. USA, 96, 3200-3205 (1999).

14. S. C. Lien, P. S. Cederna, and W. M. Kuzon, Jr., "Optimizing skeletal muscle reinnervation with nerve transfer," Hand Clin., 24, 445-454, vii (2008).

15. F. M. Love, Y. J. Son, and W. J. Thompson, "Activity alters muscle reinnervation and terminal sprouting by reducing the number of Schwann cell pathways that grow to link synaptic sites," J. Neurobiol., 54, 566-576 (2003).

16. F. A. Meunier, G. Lisk, D. Sesardic, and J. O. Dolly, "Dynamics of motor nerve terminal remodeling unveiled using SNAREcleaving botulinum toxins: the extent and duration are dictated by the sites of SNAP-25 truncation," Mol. Cell Neurosci., 22, 454-466 (2003).

17. A. A. Rogozhin, K. K. Pang, E. Bukharaeva, et al., "Recovery of mouse neuromuscular junctions from single and repeated injections of botulinum neurotoxin A," J. Physiol., 586, 31633182 (2008).

18. S. L. Tam, V. Archibald, N. Tyreman, and T. Gordon, "Tetrodotoxin prevents motor unit enlargement after partial denervation in rat hindlimb muscles," J. Physiol., 543, 655663 (2002).

19. S. L. Tam, V. Archibald, N. Tyreman, and T. Gordon, "Effect of exercise on stability of chronically enlarged motor units," Muscle Nerve, 25, 359-369 (2002).

20. S. L. Tam and T. Gordon, "Neuromuscular activity impairs axonal sprouting in partially denervated muscles by inhibiting bridge formation of perisynaptic Schwann cells," J. Neurobiol., 57, 221-234 (2003).

21. J. Ekstedt, "Human single muscle fiber action potentials. Extracellular recording during voluntary and chemical activation. With some comments on end-plate physiology and on the fiber arrangement of the motor unit," Acta Physiol. Scand., Suppl. 226, 221 (1964).

22. J. Ekstedt and E. Stalberg, "Abnormal connections between skeletal muscle fibers," Electroencephalogr. Clin. Neurophysiol., 27, 607-609 (1969).

23. J. Ekstedt and E. Stelberg, "Myasthenia gravis. Diagnostic aspects by a new electrophysiological method," Opusc. Med., 12, 73-76 (1967).

24. Y. D. Gu, "Functional motor innervation of brachial plexus roots. An intraoperative electrophysiological study," J. Hand Surg. Br., 22, 258-260 (1997).

25. E. Stalberg and J. V. Trontelj, "The study of normal and abnormal neuromuscular transmission with single fibre electromyography," J. Neurosci. Methods, 74, 145-154 (1997).

26. S. D. Nandedkar, D. B. Sanders, and E. V. Stalberg, "EMG of reinnervated motor units: a simulation study," Electroencephalogr. Clin. Neurophysiol., 70, 177-184 (1988).

27. R. T. Rousseff, A. J. Khuraibet, A. F. Al-Shubaili, and P. Tzvetanov, "Stimulated jitter in the masseter muscle: normative values," Muscle Nerve, 35, 243-245 (2007).

28. T. S. Lin and T. J. Cheng, "Stimulated single-fiber electromyography in the rat," Muscle Nerve, 21, 482-489 (1998).

29. A. I. Bain and D. M. Quastel, "Multiplicative and additive $\mathrm{Ca}\left({ }^{2+}\right)$-dependent components of facilitation at mouse endplates," J. Physiol., 455, 383-405 (1992).

30. J. Del Castillo and B. Katz, "Quantal components of the endplate potential," J. Physiol., 124, 560-573 (1954).

31. P. W. Gage and J. I. Hubbard, "An investigation of the posttetanic potentiation of end-plate potentials at a mammalian neuromuscular junction," J. Physiol., 184, 353-375 (1966).

32. J. E. Zengel and M. A. Sosa, "Changes in MEPP frequency during depression of evoked release at the frog neuromuscular junction," J. Physiol., 477, Part 2, 267-277 (1994).

33. E. Stalberg, J. V. Trontelj, and M. Mihelin, "Electrical microstimulation with single-fiber electromyography: a useful method to study the physiology of the motor unit," J. Clin. Neurophysiol., 9, 105-119 (1992).

34. M. Midrio, "The denervated muscle: facts and hypotheses. A historical review," Eur. J. Appl. Physiol., 98, 1-21 (2006).

35. S.L. Tam, V. Archibald, B. Jassar, et al., "Increased neuromuscular activity reduces sprouting in partially denervated muscles," J. Neurosci., 21, 654-667 (2001).

36. J. F. Jabre, J. Chirico-Post, and M. Weiner, "Stimulation SFEMG in myasthenia gravis," Muscle Nerve, 12, 38-42 (1989)

37. J. V. Trontelj, E. Stalberg, M. Mihelin, and A. Khuraibet, "Jitter of the stimulated motor axon," Muscle Nerve, 15, 449. 454 (1992).

38. M. B. Baslo, N. Yildiz, P. Yalinay, and M. Ertas, "Effect of triggering potential on calculations of jitter in single-fiber EMG," Muscle Nerve, 25, 906-908 (2002).

39. E. Stalberg and B. Thiele, "Transmission block in terminal nerve twigs: a single fibre electromyographic finding in man," J. Neurol., Neurosurg., Psychiat., 35, 52-59 (1972).

40. D. V. Lenihan, N. Sojitra, M. Ikeda, et al., "Stimulated jitter measurements in the assessment of recovery after peripheral nerve repair," J. Hand Surg. Br., 22, $772-777$ (1997).

41. M. Gantayat, M. Swash, and M. S. Schwartz, "Fiber density in acute and chronic inflammatory demyelinating polyneuropathy," Muscle Nerve, 15, 168-171 (1992). 